\title{
A farmer's view on the current environmental conversation
}

\author{
M.H. ADAMS \\ 51 Tondros Road, RD 17, Fairlie 7987, New Zealand \\ rocklands@kinect.co.nz
}

The brief for this paper was: "A farmer's view on protecting the soil, water and environment." However, I have headed in a slightly different direction and would like to focus on some of the tensions that exist within this brief. To help me do this, I will tell my family story starting with my grandfather James Adams. He sold both his 100 ha farm and agricultural contracting business in Duntroon, North Otago, to purchase an 890 ha farm in the Fairlie basin. In September 1950, at 42 years of age, my grandfather with his wife and eight children made the move north. Over the next 33 years he was able to acquire the neighbouring farms, effectively doubling the land area before two of his sons joined the business. Like many men from an era that included two world wars and a severe depression, James was a conservative man. He was prepared to borrow money to buy land, but not to develop it. Development had to be done out of income.

In 1983, the year that my grandfather passed away, I was finishing my Diploma of Agriculture at Lincoln University. During this time it became obvious to me that there were dark clouds gathering on the horizon for the sheep and beef industry in general, and the home farm in particular. While the Adams family had acquired a reasonable land holding, the farms were not developed and after a prolonged drought, financial reserves were depleted.

The new labour government in 1984 introduced financial reforms, though necessary at the time, these were hastily and carelessly implemented. The physical and emotional toll these reforms had on the rural community were brutal. There was a generation of farmers slightly older than me that were deeply affected and some were ripped out of the industry and never returned. These were my formative business years.

So how did we survive interest rates approaching $20 \%$, lambs valued at between $\$ 7$ and $\$ 23 /$ head and old ewes worth $\$ 1$ each? While the farm was poorly prepared when the reforms were implemented, the family came together to save the business. Both my father and uncle had served their time as shearers so we started second shearing our 9500 ewes. A ruthless focus on cost and cash flow was necessary. There were dark days working hard knowing there was no profit and that we were merely minimising our losses. However, I look back with satisfaction at what was achieved and mainly remember the humour, laughter, camaraderie and strong sense of purpose.
Rationalisation in 1993 meant some land was sold to help finance the retirement of my father and my uncle. My cousin and I split the rest of the land and 1 ended up with a 480 ha farm, currently running 4000 SU. I had spent my 20s working for little pay but in the hope that one day some of the land would be mine. So 1993 was a good year for me, 1 married Maja, and now had my name on the farm title. I was 29 years of age and living the dream.

There is nothing special about this Adams family story. Indeed, many farming families have replicated this story throughout New Zealand as they have faced adversity staying on their land. Most farmers have an attachment to their farm and believe they are doing right by the land and are frustrated when their commitment and methods are questioned. A farm is often a reflection of a farmer's views, values and stage in life. When a farmer is audited for whatever purpose it is taken very personally, and in many ways it is seen as a statement on farmer competency. Some farmers welcome the scrutiny; they enjoy a third party perspective and welcome discussion groups and field days on their property. Others do not, they find it invasive and intimidating having someone other than family or a trusted professional, looking over their property.

In 2010 I participated in the Kellogg's Rural Leadership Development programme at Lincoln University. My research project was about understanding farmer behaviour when engaging with extension opportunities. After several years of involvement with the Beef + Lamb New Zealand Monitor Farm and Farming for Profit programmes based in South Canterbury, I developed a curiosity about farmer engagement. Why some farmers choose to engage and why some do not, and for those who do, how do they measure the success or failure of that engagement?

My research suggested a number of possible influences. Lack of profitability in the sheep and beef sector, an industry that operates with low levels of trust, farmers being time poor, the age and stage of a farmer's life and education, all seem to have a bearing on willingness to engage. I believe that these themes are evident not only in extension opportunities but show themselves in all forms of farmer engagement, including dealing with professionals, bureaucrats, auditors, media as well as our urban cousins.

There are a group of farmers who leave school 
feeling like academic failures, some experiencing low self-esteem. Comments like "I only went to school to eat my lunch" and "when I left school I just headed for the hills" being commonplace. We have all heard the saying: "A farmer has two sons, he sends the brightest one to university and the dumbest one stays home". The tragedy of this statement is that a many people believe it, especially the one who stayed home. Many older farmers aren't aware of differing learning styles. Kinaesthetic intelligence has a tactile learning style where learning is more hands on than audio or visual. After leaving school, tactile learners working with their hands generally blossom as their learning becomes relevant to them. Unfortunately, in this environment tactile learners are unlikely to get the acknowledgement and affirmation needed and missed out on when younger, and often they fail to recognise their skills and achievements. This sense of inferiority can be a barrier when a university-trained professional comes up the driveway.

It is important for professionals who want to challenge or change farmer behaviour to be mindful that once they enter the farmer's property, any observation or comment may be seen as a personal evaluation. A considered approach could be instrumental in driving a culture change whereas a less considered approach at worst could offend and at best achieve minimum compliance like "How many boxes do I have to tick to make you go away?" Academic solutions for tactile problems do not work for some farmers. Increasing the output of paperwork and time spent in a farm office is not a good solution for them as they see office time as down time. These farmers cannot see that pieces of paper are going to make their farms safer or more environmentally friendly. This causes frustration that the auditor cannot see the work that has been done nor appreciates the farmer's efforts to date, and they feel that their common sense and values are not recognised. Professionals, on the other hand, tend to value time spent in the office, as that is often where they do their best work. Professionals know that common sense is a relative term and that pieces of paper won't save lives or change the environment, but recognise that it is the thought processes behind the paper trail that may. When taken to the extreme, these views can mean that professionals don't trust farmers to do the right thing, demanding that they be regulated and audited. Farmers in turn don't trust regulators to make rules fit for purpose that are practical or workable, and they especially don't trust the system to be reasonable when it all goes wrong. Emotions run high.

My concern is that these polarising views are barriers to problems being solved. How do we better understand each other's points of view so that bridges can be built and progress made? We need to take a step back and recognise that the issues are not just about the environment, but also about how people tick. It has been recognised that nothing undermines good relationships and communication like shame. The wider community have to move away from apportioning blame and playing the shame game. Pointing the finger only serves to shut the conversation down. The community needs to be able to clearly define where it is now by being honest and respectful, and then decide how it is going to address the future. All participants want good environmental outcomes.

A good example of a community's behavioural change happened in my hometown of Fairlie. As mentioned earlier, 1993 was the year that 1 got married, it was also the first time that Maja, my new Swiss wife, had ever seen a rubbish dump. She was appalled. The local unlined landfill was on shingle soils within $100 \mathrm{~m}$ of the river. Our favourite swimming spot was about 1 $\mathrm{km}$ downstream. I can remember being offended at her "extreme" reaction to something that to me was normal, socially acceptable and on occasions, useful. Maja quickly instigated her own system that had us carrying our recyclables to Timaru to quickly unload into the recycling bins in the Pak'n Save car park, when no one was looking. It was not only embarrassing but her system took up some of my valuable shed space! In 2004 the Fairlie rubbish dump was closed, as were the other dumps throughout the Mackenzie District. Resource Recovery Parks were created to take their place. There was community resistance and personal abuse directed towards the Mayor and counsellors who drove the new "Zero Waste" strategy, and abuse towards staff who had to implement the change. Key people reflecting back on that time, say it took between 9-12 months for most of the community, both rural and urban, to settle and to recognise that this change was necessary. Good strategic planning also helped facilitate the successful outcome. This included educating the Mackenzie youth through intensive school programmes. Children then challenged their parents on the need to change as they became more aware of the issues. The leadership focused on key stakeholders and other community leaders to quickly get them on board. At no time did they apportion blame to previous generations but focussed on "this is where we are now and this is where we want to go". The leaders relied on open and honest communication emphasising environmental stewardship and financial reality in the belief that reasonable people would respond.

I am using the Fairlie rubbish dump as an example because this only happened 12 years ago, and 1 don't know of anyone who would want to go back to the old way. In fact, 1 don't know anyone who would agree that the old way was ever acceptable. I think it is good to reflect on how far the community has come, both urban and rural. 
Everyone has the responsibility to consider their environmental obligations; farmers by virtue of scale and urban by virtue of density. Both must respond to current science and adjust systems accordingly. I have every confidence that despite a variety of backgrounds, farmers are well able to understand and respond to community issues.

Is it fair to land the burden of responsibility on one generation when the issues leading up to that responsibility have been accumulated over several generations? I think we need to be careful about this question. I believe that this generation can set the tone for improved environmental outcomes better than any before it by leveraging current science and accumulated knowledge. I also believe that financial and social costs need to be fully considered when agreeing on the pace of change. Poor decision making and hastily made legislation will invariably lead to unintended consequences, and may even end up with outcomes far removed from those intended. With an ageing rural workforce the food production system is vulnerable. As a younger person, would 1 want to enter an industry where I was expected to fund the clean-up from previous generations, and where productivity has been capped and returns on capital are marginal?

I love farming. I enjoy the lifestyle and spending time with people who have committed themselves to the land. I take the sustainable production of safe food seriously and endeavour to place my property and its on-farm systems at the forefront of best practice. I look forward to the maturing conversation around our environmental responsibilities and the good story that we will be able to take to the world. 
